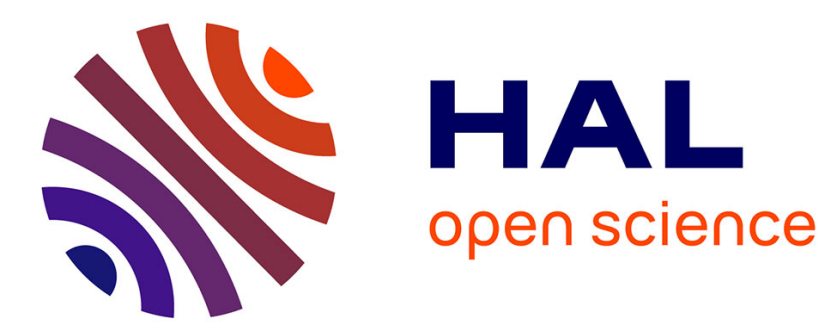

\title{
Some non-Technical Issues of self- Publishing
}

Tibor Koltay

\section{To cite this version:}

Tibor Koltay. Some non-Technical Issues of self- Publishing. ELPUB 2020 24rd edition of the International Conference on Electronic Publishing, Apr 2020, Doha, Qatar. 10.4000/proceedings.elpub.2020.9 . hal-02544220

\section{HAL Id: hal-02544220 \\ https://hal.science/hal-02544220}

Submitted on 16 Apr 2020

HAL is a multi-disciplinary open access archive for the deposit and dissemination of scientific research documents, whether they are published or not. The documents may come from teaching and research institutions in France or abroad, or from public or private research centers.
L'archive ouverte pluridisciplinaire HAL, est destinée au dépôt et à la diffusion de documents scientifiques de niveau recherche, publiés ou non, émanant des établissements d'enseignement et de recherche français ou étrangers, des laboratoires publics ou privés. 


\title{
Some non-Technical Issues of self- Publishing
}

\author{
Tibor Koltay
}

\section{AUTHOR'S NOTE}

The author expresses his gratitude to Pál Kerekes for his help in writing this paper.

\section{Introduction}

1 Publishing, financed by authors themselves is not new. In the past, many writers have paid for publishing at times in their careers, including some who have become well known, highly esteemed or even best-selling authors (Bradley, Fulton and Helm, 2012).

2 The printed book is an industrial product, generating enormous quantities of books, especially if we compare the number of copies to previous centuries. New information technologies now allow legally published textual publications not only reach the reader as a commodity but also as a free service in the sense that the reading is free for the audience, i.e. does not involve any payment (Kerekes, 2018a).

3 Self-publishing has evolved into a movement, a writer's attitude with its own press, presence in library and information science literature, and significant economic influence. While many of the successive e-book business models appeared and failed, self-publishing is one of the few exceptions that have produced a successful and sustainable model (Kerekes, 2014).

4 Taking this into consideration, this paper based on a non-exhaustive review of the literature, addresses several questions, related to the past and present of selfpublishing, giving distinguished attention to their development in Hungary. The discussion will include questions, related to the legitimacy and the history of selfpublishing, then we shall examine the roles and responsibilities of self-publishing authors. Some processes of self-publishing will be described. Self-publishing will also be 
seen through the eyes of independent editors, then through the eyes of the librarian. A few questions of self-publishing textbooks, as well as research data will be discussed. A glimpse into self-publishing in Hungary will be given, first returning to historical issues, then providing a mini-portrait of Pál Kerekes, who is the founder of the only dedicated Hungarian self-publishing site, and whose activities are closely connected to the past and present of digital publishing in Hungary.

\section{The legitimacy of self-publishing}

5 Self-publishing allows the legal downloading of books, and it is in the same time restricted to it. It is not identical with borrowing books from libraries free of charge, while free book databases are part of it. Although connected to the changing economy of book publishing and distribution, it reflects changes in our culture.

6 If we look at the history of the book, it becomes clear that codices and in the first three centuries of printing, the book itself was not considered a widely traded commodity. As a consumer product in its present sense, and as a unique cultural product, it emerged in Europe only in the 18th century, creating an exclusive system of book publishing and distribution. Subscription publishing remained a practice until the end of the Reformation, and only then did professionalism in writing and publishing finally develop. While many have condemned the book-publisher subscription-publishing industry, the system has proven to be a viable construct for sixty-seventy years. Whoever wrote the book, they were looking for their reader, even if not always successfully. By the 20th century, free book distribution was already at the periphery. The professionalization of the book's publishing and commercialization pushed the distribution toward marketability, so the reader has become a customer (Kerekes, 2018a).

7 Vide, quantum, inquam, fallare, Torquate. oratio me istius philosophi non offendit; nam et complectitur verbis, quod vult, et dicit plane, quod intellegam; et tamen ego a philosopho, si afferat eloquentiam, non asperner, si non habeat, non admodum flagitem. re mihi non aeque satisfacit, et quidem locis pluribus. sed quot homines, tot sententiae; falli igitur possumus.

\section{The self-publishing author}

8 If we look at the distribution of roles in traditional book publishing, we see that the author puts the work on paper and is not involved - or only to a very limited extent in sales, marketing, or other business activities. In the new, self-publishing environment, authors see themselves not only as a writers, but must also act as businessmen, who invest in the work they wrote (Kerekes, 2015). In this construction, it is only the author, who decides on the future of the work alone, i.e. defines the main elements, determines its price, decides in which country it is sold, etc. Self-publishing is therefore independent publishing in the sense of the authors' independence in choosing, how the content is published.

9 Someone, who has published at least one self-publishing book can be regarded a selfpublishing author. However, self-publishing does not mean that the author may or does not rely on the work of book professionals (editors, proof-readers, graphic designers, etc.). (Kerekes, 2018a). 
10 To become self-publishing author, it is necessary to acquire the information technology skills, necessary for uploading the manuscript text and title pages, as well as the socalled accessories, such as content description and genre definition.

11 Authors may make use of self-publishing portals, which performs sales, provide IT back-office work and administration, handling the billing process, or managing customer relationship issues. It also provides the author with daily tracking of book sales traffic (Kerekes, 2014).

12 Although often a matter of friendly involvement, attention to the contractual relationships is utterly important. Financial questions do not vanish as making a book, not to mention that creating content itself has always been a costly process.

Self-publishing writers recognize and acknowledge that their activities are a contribution to the transformation of the publishing structure. This is essentially because the author is not only the resource of the work, as it is today, the content provider, but also the creative director of the book (Kerekes, 2018a). As Nelson (2015, p. 153) puts it "When deciding to self-publish, the author must wear a variety of hats. Instead of turning over the manuscript and waiting to learn about the marketing plan, a self-published author has to go through the entire process. Some of the tasks are similar to writing, like proofreading and making edits".

On the other side of the coin, self-publishing is related to amateur cultural production (Bradley, Fulton and Helm, 2012). As it is relatively well-known that their most important characteristic is that they love to be engaged in a specific activity and have a particular self-identity, which is often different from that of professionals. Amateurs may be knowledgeable of their subject, but did not receive any formal training and/or do not have access to important tools or knowledge (Keen, 2011).

15 As a consequence, amateurs, many of whom do not always strive for originality are part of the self-publishing culture. Self-publishing authors are often comfortable with describing something that they have experienced, or they may be prone to choose subject matters, which are likely to be of limited interest, but still relevant for narrower target audiences. In addition to this - while self-publishing is not exclusively digital - the traditional boundaries between literary functions are partially, or in some cases completely dissolved in the digital medium, so readers often find themselves in a role that differs from their traditional one (Kerekes, 2018a).

\section{The process of self-publishing}

16 Even if it seems to be self-explanatory, producing a manuscript is a must. A selfpublishing manuscripts are not different from other writings published in print in the sense that they should measure up to basic requirements, such as being free of linguistic and spelling errors. It is inevitable to have a proof-reader and test readers should also be invited. We do not expect from these latter, lay people to provide clarity and editorial comments, but their work is indispensable for controlling the clarity of language in the book. Engaging a graphic designer for creating the on-screen cover page is a more than useful.

17 It is expedient to publish the new work as an e-book, because the digital version allows deciding if it was viable to produce it. Only when the purchase has begun and the reader's demand can be felt, is it only worthwhile to examine if producing a printed 
edition is practicable or not. We should not forget either that many e-books are structured in such a way that a print derivate cannot be created from it (Kerekes, 2015).

The writer controls many stages of the publication process. As said above, the first stage begins with content creation and editing. The majority of the stages have to be completed by the writer, but not all of them. For example, they can delegate the distribution up to a commercial firm. Marketing is frequently done on the website of the writer or of a self-publishing service.

Print-on-demand, offered by the writer or by commercial distributors is one of the possible distribution channels of self-published books. Naturally, this does not mean that all print-on- demand items are self-published. Neither are all self-published items published via print-on- demand, but print-on-demand is related to self-publishing, because it is one of the tools that produce an end-product of the self-publication process (Tuncer, Nurhak, and Reed David, 2019).

\section{Self-publishing through the eyes of independent editors}

20 A 2013 survey explored the role of independent editors in traditional publishing environments and in the light of self-publishing's growth. It was found that among these editors there is a clear shift from being employed by traditional publishers towards working for new clients, including self-publishing authors. In the light of the often-held assumption that self-publishing authors manage the publishing process themselves, this was a surprising result.

21 Many freelance editors leave the traditional publishing industry and offer they services to self- publishing authors, because they often perceive a decline in publishing quality due to the apparent actions of publishers to get rid of much of their internal staff by outsourcing editorial and production work to cheaper locations. This move usually results in one-to-one and unmediated relationships between authors and editors.

In general, independent editors are gaining increasing levels of satisfaction from working for self-published authors. In the same time, there are risks for editors, first of because of unrealistic and unreasonable demands from new and inexperienced authors. However, working with competent authors may offer significant rewards for them, because most of these authors are able to appreciate the value that editors bring into the book production (Baverstock, Blackburn, and Iskandarova, 2015).

\section{Self-publishing through the eyes of the librarian}

23 As Cassell $(2015$, p. 27) put it, "there has generally been a stigma attached to a selfpublished book, particularly for academic libraries". It was often thought that selfpublishing means that these books are of inferior quality, thus rejected by traditional publishers, while we know that many well-known writer's first books were published by themselves.

Book authors who needed a publisher, but did not want to go through the usual channels always had the possibility to use the services of "vanity presses", the nature of which is somewhat inexactly defined. These publishers have served authors, targeting 
niche audiences, while others simply published anything subsidized by the author (Laquintano, 2013).

Libraries could gain advantage to work out ways to be involved with non-traditional publishing, instead of ignoring it. Such moves require participating in community-wide discussions, experimentation, and cooperation. If only on a smaller scale, but the development of digital publishing changed the attitudes of librarians toward selfpublished books. Today, a growing number of libraries are acquiring and making these books available to their users, even though collecting and cataloguing them raises several questions (Landgraf, 2015).

Collecting self-published books has always been an option for libraries, but - as being a minor part of the publishing world - they were mostly ignored (Dawson 2008). On the other hand, the dilemmas related to collecting self-published books by libraries highlights not only their dual role as archivers and developers of collections for their communities, but also points out that large publishers are no more the sole arbiters to decide which books will be useful and successful (Bradley, Fulton and Helm, 2012).

Although libraries typically do not go out and look for self-published materials, they are collecting self-published books. Acquisition is on a case-by-case basis, either by buying these books, or sometimes accepting them as gifts, especially if they include content not available elsewhere, which may happen relatively often. Identifying such books is a problem; evaluating them is difficult, because they are rarely reviewed.

When written by teaching staff members, employees, alumni of universities, or tied to local institutions, self-published books are bought more willingly. In such cases, it is easier to make decisions about acquisition, because librarians know something about the author that could help in making judgements about the quality of writing or any other deciding factor. Books on subjects of local (regional) interest and authors are usually welcome. This is true not only for local libraries, but to academic ones, as well. Libraries' involvement in self-publishing involves not only collecting books, but participating in their production, as well (Cassell, 2015).

Holley (2015) enumerates a wide range of arguments for accepting or rejecting selfpublished books. First of all, such decisions depend not only on their content, but on the quality of editing, typography, and substandard illustrations.

Public libraries are more likely to deal with of self-published materials, because they require a steady supply of new fiction books, while academic libraries tend to avoid purchasing most self-published materials, among others because most scholars typically publish with traditional academic publishers, and self-published works are not valued for promotion. On the other hand self-published books, such as autobiographies or personal narratives can be excellent primary source material, because they offer a more direct perspective. Self-published materials also reflect the popular culture of the given era by recording the ideas of writers, who are outside mainstream publishing.

31 Librarians should take into account that one of the principal reasons to choose selfpublishing is the fact that publishing these works is not economically viable for commercial or university press publishers, even if they report excellent scholarship, but with a narrow focus, especially in the humanities and partially in the social sciences. 
32 As Bradley, Fulton and Helm (2012) underline it, the author-generated nature of selfpublished books show considerably less bibliographic control, compared to works that have the imprint of traditional mainstream publishers. If bibliographic data are nonstandard or not available, systematic documenting may become difficult. Cataloguing self-published books can be challenging, therefore such items require either original cataloguing or complex copy cataloguing, coupled with the need for some outside research (Tuncer, Nurhak, and Reed David, 2019).

\section{Self-publishing textbooks}

33 Apparently, there is a new market for writing online textbooks, which is successfully exploited by some teaching staff (faculty) members (Cassell, 2015). Writing textbooks is far from being easy and simple. It is time consuming, and it may be difficult to balance writing with teaching, research, and service requirements. On the other hand, authors have not only control over content, but they have the ability to update their texts much quicker than in traditional publishing systems, which is crucial if publishing textbooks. Even more, in some cases updates can be pushed out to everyone who has purchased the book. Another consideration in the decision to self-publish a textbook is the ability to produce supporting material for teaching in a timely manner (Schultz, 2017). The process of writing and revision of self-published textbooks also has a potential of fostering cooperation with other teaching staff members (Cassell, 2015).

Obviously, there are concerns for the quality of the presentation of the information, and decisions have to be made about the appropriate scope of information. Many of them originate in the lack of critical review (Schultz, 2017).

Among the reasons to consider self-publishing online open-access textbooks, we see financial benefits both for the authors themselves and for their audiences. This way of publishing textbooks offers low prices for students and an increase in authors' supplemental income. Both outcomes stem from the ability of the authors to save costs and to set their own price. They also can give discounted or free copies to their students. Besides of this, authors can generate additional income by marketing their woks to other teaching staff members or a general audience. As prices are set lower compared to traditional print textbooks, some authors may reach a wider audience that normally would not be possible considering the usually high prices of textbooks (Schultz, 2017).

36 Last, but not least, providing self-published textbooks may be an exciting development for academic libraries (Holley, 2015).

\section{About self-publishing research data}

Self-publishing of research data is also worth mentioning, although it is not directly related to the self-publishing of books. The background to it is given by the fact that thanks to the high capacity of computers to store massive amounts of data and forward them on high bandwidth networks - we live in a data-intensive era, which is characterised by an interest in research data, never seen before.

Data publishing itself is a new trend, which has the potential to become a source of motivation for researchers to share their data, because it allows the provision of 
measurable and citable output. Its main channels are curated data repositories and data journals (Austin, 2017). Self- publishing repository systems are not different in the sense that they require data to meet quality standards. On the other hand, they must enable easily self-publishing. One example of such repositories is the ReShare selfdeposit data repository, developed in 2014. It is based on the customised version of the Eprints open-source repository software, and serves data publishing for social sciences research data in the UK. ReShare enables researchers to collect research data and to make them available for use by other researchers (Van den Eynden, Veerle, and Corti, 2017).

\section{A glimpse into self-publishing in Hungary}

The last part of this paper is limited to two issues. The first one reveals an interesting historical example of free access to books. The second one provides a mini-portrait of Pál Kerekes, who is the founder of the only dedicated Hungarian self-publishing site, runs a general blog on e- books, researches e-books and teaches about them in a school of library and information science.

Compared to European developments, described at the beginning of this paper, there was a one hundred and fifty years lag in Hungarian book publishing and distribution. Towards the end of the 18th century, the practice of subscribing to books has become an established way of making a book a marketable product, or rather a product at all. The writer has collected subscriptions to his book in preparation in order to pre-certify the profitability of publishing his work for the printing press (or publisher). This development clearly demonstrates from a historical point of view that the "reader pays for the book" principle was far less obvious, than it is today (Kerekes, 2018a).

While several (traditional) publishers are involved in the business of self-publishing books in Hungary, there is only one specialized company, called Publio (http:// publio.hu/) is dedicated exclusively to self-publishing (Kerekes, 2018b).

\section{Conclusion}

Without wanting to repeat what was said in this paper, we summarise some of the most important characteristics of self-publishing by following the thoughts of Holley (2015). First of all, self-publishing is a publishing model that differs from that of the traditional mainstream publishing industry, because it is service-driven, relies on writers who are willing to pay for publication. Besides of this, publishing industry standards of book creation and production are not enforced on the self-publishing process. Instead of being based on corporate decision of what audiences want to read, self-published books reflect for better or worse what people want to say to readers. Libraries are aware of these developments and do what they are supposed to do, i.e. selectively collecting and cataloguing self-published books. 


\section{BIBLIOGRAPHY}

Austin, Claire C., et al. "Key Components of Data Publishing: Using Current Best Practices to Develop a Reference Model for Data Publishing." International Journal on Digital Libraries, vol. 18, no. 2, June 2017, pp. 77-92. doi:10.1007/s00799-016-0178-2.

Baverstock, Alison, et al. "How the Role of the Independent Editor Is Changing in Relation to Traditional and Self-Publishing." Learned Publishing, vol. 28, no. 2, Apr. 2015, pp. 123-31. doi: $10.1087 / 20150206$.

Bradley, Jana, et al. "Self-Published Books: An Empirical 'Snapshot.” The Library Quarterly, vol. 82, no. 2, Apr. 2012, pp. 107-40. doi:10.1086/664576.

Cassell, Kay Ann. "Do Large Academic Libraries Purchase Self-Published Books to Add to Their Collections?" Self-Publishing and Collection Development: Opportunities and Challenges for Libraries, edited by Robert P. Holley, Purdue University Press, 2015, pp. 27-36. doi:10.2307/j.ctt1wf4dpf.7.

Dawson, Laura. “The Role of Self-Publishing in Libraries." Library Trends, vol. 57, no. 1, 2008, pp. 43-51. doi:10.1353/lib.0.0021.

Holley, Robert P. "Why Academic Libraries Should Consider Acquiring Self-Published Books." SelfPublishing and Collection Development: Opportunities and Challenges for Libraries, edited by Robert P. Holley, Purdue University Press, 2015, pp. 37-46. doi:10.2307/j.ctt1wf4dpf.8.

Keen, Andrew. The Cult of the Amateur: How Today's Internet Is Killing Our Culture. Doubleday/ Currency, 2007.

Kerekes, Pál. “Self-Publishing: Könyvcunami Vagy Könyvmegújulás? A Könyvönmenedzselés Néhány Jellemzője, Nagyságrendje, Tendenciái.” Tudományos És Műszaki Tájékoztatás, vol. 61, no. 6, 2014, pp. 235-41, tmt.omikk.bme.hu/tmt/article/view/403.

Kerekes, Pál. Self-Publishing: Az Ön-Menedzselésü Független Könyv Irodalmi És Kiadói Modellje. Kossuth Kiadó, 2015.

Kerekes, Pál. “Könyvingyenesség a Nyomtatott És a Digitális Korban.” Korunk, vol. 29, no. 2, 2018, pp. 112-17, real.mtak.hu/75159/

Kerekes, Pál. “Self-Publishing. A Könyv-Önmenedzselés Irodalmi És Kiadói Modelljéről.” Valóságos Könyvtár - Könyvtári Valóság: Könyvtár- És Információtudományi Tanulmányok 2018, edited by Péter Kiszl and Tibor Csík, 2018, pp. 181-89. doi:10.21862/vkkv2018.181.

Landgraf, Greg. “Solving the Self-Published Puzzle.” American Libraries, vol. 46, no. 11/12, 2015, pp. 44-47.

Laquintano, Timothy. "The Legacy of the Vanity Press and Digital Transitions." The Journal of Electronic Publishing, vol. 16, no. 1, Oct. 2013. doi:10.3998/3336451.0016.104.

Nelson, Elisabeth. "The Romance of Self-Publishing." Self-Publishing and Collection Development: Opportunities and Challenges for Libraries, edited by Robert P. Holley, Purdue University Press, 2015, pp. 149-58. doi:10.2307/j.ctt1wf4dpf.16.

Schultz, Leah A. "Navigating the Minefield of Self-Publishing E-Textbooks." Information Systems Education Journal, vol. 15, no. 5, 2017, pp. 15, https://files.eric.ed.gov/fulltext/EJ1151721.pdf

Tuncer, Nurhak, and Reed David. "The Cataloging of Self-Published Items.” Cataloging \& Classification Quarterly, vol. 57, no. 4, May 2019, pp. 206-26. doi:10.1080/01639374.2019.1602091. 
Van den Eynden, Veerle, and Louise Corti. “Advancing Research Data Publishing Practices for the Social Sciences: From Archive Activity to Empowering Researchers." International Journal on Digital Libraries, vol. 18, no. 2, June 2017, pp. 113-21. doi:10.1007/s00799-016-0177-3.

\section{ABSTRACTS}

From among the varied non-technical issues, related to self- publishing, the history of subscription-based book publishing is addressed first, followed by a discussion of selfpublishing's legitimacy, then by an examination of self-publishing authors' roles and responsibilities. Subsequently, some processes of self- publishing are described, its relationship to independent editors discussed. Self-publishing is also explored through the eyes of the libraries and librarians. Some of the related issues, including motives for publishing selfpublished textbooks are dealt with. A short discussion directs attention to the possibility of selfpublishing research data. Last, self-publishing activities in Hungary are shortly presented.

\section{INDEX}

Keywords: self-publishing, history, libraries, data publication, Hungary

\section{AUTHOR}

\section{TIBOR KOLTAY}

Eszterházy Károly University

Email: tkoltay@freemail.hu 